\title{
On the Occasion of an Anniversary, Eh: Confessions of a Canadian Math Ed Editor
}

\author{
Egan J. Chernoff $($ i)
}

Accepted: 7 September 2020 / Published online: 16 October 2020

(C) Ontario Institute for Studies in Education (OISE) 2020

\begin{abstract}
As its title suggests, this commentary utilizes the 20th year of publication of the Canadian Journal of Science, Mathematics, and Technology Education as an opportunity for me, the current English language mathematics education editor, to confess. I confess to imposter syndrome and editorial naiveté. I confess to evolving from putting the pathetic in empathetic to near-total emotional desensitization. I confess to having stumbled upon the notions of form letters and desk rejections. I confess that my former French teachers would be disappointed in me. I confess to having never forgotten my first, to seeing ghosts, and to attempting to handle multiple concurrent timelines based on the geologic time scale. Lastly, most importantly, and utilizing an entirely different meaning of the word confess, I confess to giving credit where credit is due. In other words, what follows are the absolutely true confessions of a Canadian mathematics education editor.
\end{abstract}

Résumé Comme son titre l'indique, ce commentaire profite de la $20^{\mathrm{e}}$ année de publication du Canadian Journal of Science, Mathematics and Technology Education pour me donner l'occasion, en tant qu'actuel rédacteur anglophone pour l'enseignement des mathématiques, de faire des aveux. J'avoue avoir été atteint du syndrome de l'imposteur et avoir fait preuve de naïveté éditoriale. J'avoue avoir évolué d'une empathie pathétique à une désensibilisation émotionnelle quasi totale. J'avoue être tombé sur des esquisses de lettres types et des manuscrits rejetés par le pupitre. J'avoue que mes anciens professeurs de français seraient déçus de moi. J'avoue n'avoir jamais oublié ma première fois, avoir vu des fantômes et avoir tenté de gérer de multiples chronologies simultanées basées sur l'échelle de temps géologique. Enfin, le plus important, et en utilisant un sens complètement différent du mot « avouer », j'avoue donner à chacun le crédit qui lui revient. Autrement dit, les lignes qui suivent présentent les aveux tout à fait vrais d'un rédacteur pour l'enseignement des mathématiques canadien.

Keywords@CJSMTE·Anniversary·Commentary·Confession·Editorial · Mathematics Education

E. J. Chernoff $(\bowtie)$

University of Saskatchewan, Saskatoon, Saskatchewan, Canada

e-mail: egan.chernoff@usask.ca 
Manuscript ID UCJS-2015-0049 now in your Editor Centre

30-Jun-2015

Dear Egan:

The above manuscript, entitled “..." with "..." as contact author, has been assigned to you and is awaiting reviewer selection. Please go to your Editor Centre at https://mc.manuscriptcentral.com/ucjs and select reviewers by 03-Jul-2015. Note that after picking your reviewers, you will need to click on "Invite" to send an e-mail and complete the task.

If, for any reason, you are unable to serve as Editor for this manuscript, please contact your Editorial Assistant at cjsmte@utoronto.ca

Sincerely,

\section{ScholarOne}

The majority of that day, June 30th, 2015, the day I received my first ever manuscript as a math education editor, was spent driving from Saskatoon, Saskatchewan to Jasper, Alberta. The thing is, I did not have a data plan for my phone back then, which means that I would not have been able to check my email during the long drive. Once we got to Jasper, the rest of the day was dedicated to pitching a tent, looking for the closest washrooms, getting water, getting firewood, and, in general, familiarizing ourselves with Whistlers Campground. Digging deeper into my email records, I see that I responded to the email the next day, July 1st, which meant that I read it a day after it arrived in my inbox. Here is my response:

Would you mind delaying my selection of reviewers deadline until the 6th. A combination of this being my first selection as editor, me travelling for a few more days and spotty internet connections mean that a few extra days for my first assignment would be much appreciated. Thank you for accommodating this request, which will be the exception rather than the rule.

Sincerely,

Egan

Looking back at photos from the trip, I see that I used (what is now called) the SHAW Go WiFi hotspot at the Bear's Paw Bakery, located in downtown Jasper, to download the email to my phone and craft my response. I also know that I went back to the very same spot, the very next day, to check for a response. It read as follows:

Hi Egan:

Please consider these reminders as automatic messages sent by the system (it will occur every 3-6 days). Unfortunately, there is no way I can deactivate them.

Do the selection of reviewers when you are ready and please do not worry if the system indicates (in red) that you are overdue. 
Let me know if you have any doubt.

Best,

[CJSMTE Editorial Assistant]

Two things are abundantly clear from the above email exchange regarding my very first assignment as editor for the English-language mathematics submissions to the Canadian Journal of Science, Mathematics and Technology Education (hereafter denoted with the journal's Twitter handle, @CJSMTE). First, important moments in your life leave indelible imprints in your memory. For me, becoming the mathematics education editor for @ CJSMTE was a big deal, and my very first editorial assignment also marked the beginning of my tenure. Second, my request for an extension, sent in response to an automatic message created by "the system" and concerning dates that weren't really that important, demonstrated that I had a lot to learn. I should point out that the period of time between my name being floated for editor (in the early months of 2015), me being appointed editor (May 1, 2015), and my first assignment (June 30, 2015) left ample time for doubts of all sorts to creep into my mind. And creep in they did.

\section{Math Ed Editor (I Think I Can, I Think I Can)?!}

I was not entirely new to the game when I was appointed mathematics editor of @CJSMTE. By May of 2015, I had reviewed manuscripts for Asia Pacific Education Review, Canadian Journal of Education, and Computers in Human Behavior. More specific to the field of mathematics education, I had also reviewed for Digital Experiences in Mathematics Education, Educational Studies in Mathematics, Fields Mathematics Education Journal, Journal for Research in Mathematics Education, Journal of Mathematics Teacher Education, Mathematical Thinking and Learning, Nordic Studies in Mathematics Education, The International Journal of Science and Mathematics Education, ZDM: The International Journal on Mathematics Education, and @CJSMTE. Not bad, in my opinion. In addition to reviewing manuscripts for refereed journals, I also served as a reviewer for refereed conference proceedings in the field of mathematics education.

On a yearly basis, I would (and still) review between two and four manuscripts for the annual meeting of the International Group for the Psychology of Mathematics Education (or PME) and the North American Chapter of the International Group for the Psychology of Mathematics Education (PMENA). I also did a fair bit of reviewing and coordinating reviews for various Divisions and Special Interest Groups for the 2012 Meeting of the American Educational Research Association (AERA) when it was held in Vancouver, and had conference reviewing responsibilities with the 9th and 10th International Conference on Teaching Statistics (ICOTS-9 and ICOTS-10) and the 12th, 13th, and 14th International Congress on Mathematics Education (ICME-12, ICME-13, and ICME-14). All this, in addition to my various editorial affiliations, had helped to prepare me for my new role as editor with @ CJSMTE.

As a member of a few editorial boards prior to my posting at @ CJSMTE (e.g., Fields Mathematics Education Journal, The Mathematics Enthusiast, and Vector: Journal of the British Columbia Association of Mathematics Teachers), I was able to peek a little further behind the editorial curtain for both academic and practitioner mathematics education journals. When it came to practitioner journals, as the editor of vinculum: Journal of the Saskatchewan Mathematics Teachers' Society, I was the man behind the curtain, which meant that, technically, I was an affiliate editor for the National Council of Teachers of Mathematics (more commonly known as the NCTM). As I detail in Chernoff (2010), however, becoming the accidental editor of a non-refereed journal was deemed by me, for years, as a tactical error in my very young academic career when it came to my path to tenure and promotion. Eventually, I got over my accidental-editor's remorse and stayed with the journal that I had rebooted for another 6 years. I enjoyed my time with vinculum 
for all 8 years that I served as editor, but by 2015 , I felt that it was time to move on and was in the process of handing things over when the @ CJSMTE offer was presented. Good timing, in my opinion.

By 2015, I had already been involved with @ CJSMTE in a number of different ways. Having published in the journal (e.g., Chernoff \& Mamolo, 2015; Chernoff \& Russell, 2012), having reviewed a considerable number of manuscripts (15 in total between 2007 and 2015), and having served as an editorial board member (2012-2015), I was more familiar with @CJSMTE than any other math education journal at that point in my career. Ok, I have tried to convince myself for long enough now (i.e., 5 paragraphs) that I was indeed a viable candidate for the position, which brings us to 2015 and the start of my tenure as math ed editor of @CJSMTE.

The plan for the remainder of this article, then, is to take you along the journey that has been my editorial involvement with @ CJSMTE for the past 5-plus years. Along the way, I will touch upon major milestones, such as the move from Taylor and Francis to Springer. However, I will not share all of the details, like the time I had to sneak in through a side door to watch the "Presentation of major journals in mathematics education by their editors" (Thematic Block C of the Early Career Research Day at ICME-13), while sitting, as editor of @CJSMTE, in a sea of math education Ph.D. students. With a mix of the professional and the personal, my goal is to give you, the reader, a peek behind the curtain of my experience as English mathematics education editor of @ CJSMTE. Let's begin.

\section{The Time of Taylor and Francis (2015-2017)}

Putting the Pathetic in Empathetic (2015)

Assuming the role of editor in the middle of 2015 meant two things. First, there were a number of math education manuscripts at various stages of acceptance and publication already in the system. My responsibility, when it came to these articles, was nothing more than reading them at the proofs stage in order to catch any issues that may have been missed during previous stages. Second, I had to attend to the 21 manuscripts that were submitted during the second half of the year.

My editorial naiveté was clearly on display while managing manuscripts in 2015. I knew it then, and I know it now, that the rejections I received to my own manuscripts that I had submitted to various journals over the years were clouding my editorial judgment. Sure, these days, getting my research rejected is like water off a duck's back, but this was definitely not the case when I first started out. Rejections, especially early on in one's career, can be devastating. Recognizing this, I was hesitant to reject manuscripts without first sending them out for review. (Don't laugh.) After all, the authors had not only gone to the effort of putting their manuscripts together, they chose to submit them to @ CJSMTE. Sometimes, they even went so far as putting together a cover letter, printing said letter, signing the bottom of said letter, scanning the printed and signed letter, and attaching it to their manuscript. After all the effort put into the cover letter alone, I felt that, at the very least, I should send the article out for review.

As you all know, when submitting their reviews, reviewers have the opportunity to submit confidential comments to the editor. I am paraphrasing here, but here is one of the earlier confidential comments I received from a reviewer: "We all know this article had zero chance of ever getting published. I can see no reason why this article was ever sent out for review. I want my time spent reviewing this article back, please." ("Please" - how Canadian!) Initially thrown by the comment, I am now glad that it was made when it was made during my tenure as editor. I learned a very valuable lesson early on about not wasting my most valuable resource: reviewers. And so, I resolved to stop putting the pathetic in empathetic. Next year was going to be different.

At this point, I would be remiss not to thank all those reviewers who were kind enough to spend their time and effort reviewing those - to put it kindly — questionable articles in 2015. I was learning, and your patience during this time was very much appreciated. 
As 2015 turned to 2016, I followed up on the important lesson I had learned the previous year: Do not waste reviewers' time with manuscripts that should simply be rejected (or substantially revised before even being considered). Becoming desensitized, I am afraid to admit, was not that hard. The hard part was managing the time and effort that I was spending on the letters I sent out to authors whose manuscripts were rejected without being reviewed. As it would turn out, I was not as desensitized as I had thought.

While I had believed that I had eliminated my empathy when it came to accepting or rejecting manuscripts, it turns out that I just shifted where I was displaying my empathy. For example, if I was going to simply say, "Thanks, but no thanks," to a manuscript (especially one with an elaborate cover letter and digital signature), I felt that the very least that I could do was to let the author or authors know exactly why their manuscript was not even being sent out for review, and to offer suggestions for improving their article. This way, I reasoned, they might have a better chance of publishing the manuscript elsewhere. "No big deal," I thought. But then I ran the numbers, and things did not look good.

Extrapolating from 2015 numbers - that is, 21 submissions, with barely a handful that should have rightfully been sent out to reviewers - I realized to my dismay that I was going to be writing a lot of detailed Reject Without Review decision letters in 2016. With my own research projects, teaching, and other forms of service, I simply did not have the time to write all of these letters. A new form of editorial remorse, different from what I had experienced and discussed in Chernoff (2010), was slowly starting to creep in. Fortunately, a number of events soon happened that helped me learn how to manage my new editorial role.

Having not attended the Canadian Mathematics Education Study Group/Groupe Canadien d'études en Didactique des Mathématiques (CMESG/GCEDM) in the previous 2 years, and with around 1 year of editorship at @CJSMTE under my belt, I attended the 2016 annual meeting with the journal first and foremost in my thoughts. After chewing the ear off of one of the conference organizers, and after one of the founding editors of @CJSMTE indicated, in personal conversation, that they were pleased I had taken on the position, I decided to hold an Ad Hoc Session to discuss the journal.

A CMESG/GCEDM Ad Hoc Session is just as it sounds; however, that does not mean that Caroline Lajoie (current French language mathematics editor) and I did not have a plan. Prior to the session, we shared our desire for a greater number of contributions from members of the Canadian mathematics education community, for example. Thanks to the attendance of a former editor, a Founding Editor, and an early, consistent contributor to the journal, all others in the room were treated with interesting historical details about the journal (e.g., @ CJSMTE, according to the Founding Editor in attendance, was "born" at CMESG/GCEDM). Questions about past and present aspects of the journal were then posed, new developments were discussed (e.g., DOI demarcations, Editorial Board changes, history, social media presence, etc.), and, just like that, the session was over. Should you be interested, further information about the session is preserved in Chernoff (2017). After the conference, thanks to the people who attended the Ad Hoc Session, and thanks to my newly hatched plan to promote the journal to those presenting the New Ph.D. Reports, that year there was a marked increase of submissions from Canadian mathematics educators. This brings me back to the editorial workload issue I was trying to cope with.

The Canadian mathematics education community is teeming with members holding prominent editorial roles at prominent mathematics education journals. Aware of my role with the journal, many of them took it upon themselves to ask me, "How are things going?" Comfortable with many members of the CMESG/ GCEDM community, I did not really hold back on how I could not comprehend how they managed the time and effort it took to politely pass on certain submissions to their journal. If I was handling around 40 submissions a year over at @ CJSMTE, then, given the journals that they were involved with, I figured that these editors must not be getting any sleep at all. To my surprise, every single one of them looked at me like I was crazy: "You do what?!"

I have suffered from a certain, let us call it, condition for as long as I can remember. I am sure that there is a psychological phenomenon to describe my affliction, but I am just going to try to explain it with an 
example. Here it goes: I do not steal; therefore, I (incorrectly) assume that other people do not steal, either. I tend to apply this "logic" to virtually all other areas of my life. When I was in school, for example, I did my homework, so I assumed that everyone else did their homework, too. Far too often, I assume that people are thinking, doing, and acting the way that I think, do, and act, which, far too often, I later find not to be the case. Time and again, I have been burned by this assumption. But whether or not I get burned, I always learn.

In the context of my role as @ CJSMTE editor, this condition had led me to assume, incorrectly, that all of the other mathematics education editors were also spending an inordinate amount of time and effort responding to authors whose work would not be sent out for review. Returning to the conversation at that year's CMESG/GCEDM, an editor asked to see my general rejection letter, the one that I would send out when a submission was not ready to be sent to reviewers. I responded that I did not have one. They then asked to see the letter that I sent back when a submitted manuscript did not align with the Aims and Scope of the journal. My response was the same: “I don't have one." A few more inquiries-same answer. I started to realize what needed to be done.

The idea of form letters (how had I not thought of it myself?!) was a game changer. Continuing, said editor, the one I was discussing things with, explained, due to the number of submissions that they received for their journal (hundreds per year), that there was just no way that they could dedicate the same time and effort to everything that was submitted. Blowing my mind further, they revealed that they had in their quiver (their term) many different form letters for the many different scenarios they encountered. So, for example, if a submission had major language issues, the corresponding form letter - the one about language issueswould get sent out. It bears repeating: Mind. Blown. I quickly realized that I needed to start building my own@CJSMTE quiver. Yes, it would take time, but once my quiver was full and could address the breadth of submissions, I knew that life would get easier. (Here, I would like to thank this particular person for that particular conversation, which allowed me to see my role in a whole new way.)

Not too long after the conference, sitting in a hiring meeting with the Head of one of the other Departments in my College, I asked to see his general reject-without-review letter. He pulled it up on his computer screen within seconds. When I asked him if he had any others, they, too, were up on the screen in no time flat. After giving them all a quick read, I asked how and when these were used. His response: “Aren't you the editor of some journal?" Playing coy, I said, "Yeah, but I want to get a sense of your criteria..." They were, essentially, the same as those of the mathematics education editors I had conversed with earlier. At this point, it was time to start building my own form letter database and eradicate my editorial empathy once and for all.

\section{Learning to Watch The Red Wedding (2016)}

I once heard that the easiest way to desensitize yourself to something is through exposure. In the world of video games, playing hour after hour of Grand Theft Auto, apparently, can desensitize you to stealing cars, assault, and much, much worse. In the world of television, by way of another example, the second time you watch The Red Wedding (the uninitiated should read about it before watching, in my opinion) is easier to digest than the first; the same is true for consecutive episodes of Game of Thrones or The Walking Dead. Knowing this, I knew I had to desensitize myself to facilitate the process of writing and sending rejection letters for @ CJSMTE. The question was what, exactly, I should expose myself to (poor choice of words, I know) so that I would become dead enough inside to write and send those reject-without-review form letters.

In the process of trying to figure out what, for me, would be analogous to binge-watching The Walking Dead, I ran into happenstance. In the end, all it took was one well-timed rejection letter in response to one of my own manuscripts that I had submitted for publication. I will admit, it was not my greatest submission. With that said, I had put in all that time and effort, formatted the entire piece for that specific publication (which had some weird particulars, I must admit), wrote a nice cover letter, and even did the whole digital 
signature thing. The response I got in return was, in terms of timing and effect, perfect. I equate its impact on me to propping my eyes open with toothpicks and being forced to read a million form rejection letters in $24 \mathrm{~h}$, Clockwork Orange style. The letter in question? Here it is, in full: "Thank you for your interest in our journal, but this wouldn't be a fit for us at this time. Take care and be well."

After this rejection, I would never be the same again in my still-new role as editor of @ CJSMTE. Fortunately, I did not become fully dead inside, editorially speaking. I was able to find a nice middle ground and begin to build my quiver full of various form letters. My new process, the one that I still use to this day, still involves a careful reading of all submitted manuscripts as soon as possible. That has not changed. What has changed, though, is that authors are informed sooner rather than later if their article will not be sent out for review. I am able to do so, of course, thanks to the form letters, which still receive varying degrees of annotation; like I said, I am not completely dead inside. Thanks to conversations with colleagues, the 36 submissions that I handled in 2016 were quite manageable, and I finally felt that I was handling everything in a time-appropriate manner. In fact, by the end of the year, I felt that I hit my stride when it came to handling submissions. Funnily enough, 2016, the year of desensitization, would also be the year that I first saw in-print articles I was involved in from start (submission) to finish (publication), which resulted in a new type of sensitization.

\section{You Never Forget Your Firsts (2016)}

As mentioned earlier, I joined the editorial team in May of 2015, which roughly corresponds to the publication of issue 15(2). Given various factors, including the transition from one editor to another and the timeline associated with getting articles from submission to print, the articles that I was involved with from start to finish as an editor did not appear in issues 15(3), 15(4), 16(1), or even 16(2). It was not until @ CJSMTE issue 16(3) that I saw in print, for the very first time, articles that I had stewarded from submission to publication. (I should stress that I am not trying to take any credit by identifying the authors or their research - it was all them. That said, I am very happy to have been involved in the publication of many great manuscripts that have now become established pieces of mathematics education research literature.)

It is a phrase I have used before when writing about certain mathematics education experiences: You never forget your first time. And once again, it rang true for me. As I opened the pages of 16(3), I perused the articles of Kajander \& Holm (2016) and Kontorovich (2016) before reading anything else. Alright, I will be honest: I did not peruse - I pored over those articles looking for something, anything that I might have missed in my new role as editor. As I read them, I was able to recall the exact moments during my camping trip along the coast of Western Washington and Oregon when these manuscripts first popped up in the email inbox on my second-generation iPad. I could recall the where and the when of the revisions, the responses, the other revisions, and the publication stage. This recollection of details, I am sad to say, has not been maintained as I became involved with more and more articles. Case in point: The very next issue, 16(4), includes four articles focused on mathematics education whose publication I had overseen as editorZazkis (2016), Smith et al. (2016), Chorney et al. (2016), and Rodney et al. (2016) - but I am unable to recall many of the details of their submission-to-publication journey. In other words, the sensitization I was experiencing was slowly getting desensitized. Based on the manner in which the year began, which was heavily focused on rejections, juxtaposed with the manner in which the year ended, which was heavily focused on publications, 2016 felt like an important year of my editorial tenure. Whether it was true or not, I felt that I had found my editorial footing. Having now dealt with rejections and publications, I looked forward to another year with @ CJSMTE with a new sense of confidence.

Learning to Play the Long Game (2017)

Given the baptism by fire that I underwent during my first few years at the journal, I remember thinking that I must have, by now (now being 2017), considered and experienced absolutely everything there is for an 
editor to consider and experience. After all, I had developed a system. Of course, my naiveté would shortly be exposed.

My system was, and still is, based on the notion of handling multiple concurrent timelines. At certain times, life is easy. For example, reviewing an article that was just submitted while, at the same time, waiting for the reviews for an article sent out a few weeks ago is easy to handle. At other times, I find myself in a confusing menagerie of initial reads, finding reviewers, final decisions, late reviews, decision letters, submitted revisions, alternative reviewers, and on and on, all with different deadlines. The more articles in the system, the more difficult it is to keep track of things, but my system of designating tasks as needing to be done immediately, in a week or so, in a few weeks, or in the not too distant future was working pretty well.

With its imprecise time frames, this system may not sound very rigorous, but for me it is effective because it captures abstract notions of time. The inspiration for my system is the geologic time scale. By breaking down the tasks that I need to complete into ages (immediately), epochs (in a week or so), periods (in a few weeks), and eras (in the not too distant future), I am able to organize my tasks according to abstract notions of time and then complete them in real or concrete time. For example, an article in the epoch timeframe might be pushed to the period timeframe thanks to a delayed review, only to move back to epoch after a quick review from a member of the editorial board. With my system in place- - which, I admit, works much better in my head than how it looks on paper-I thought I had a handle on things. Unfortunately, I failed to realize that I had missed an entire unit of time.

While I finally had a handle on ages, epochs, periods, and eras, I would come to realize that I had failed to take eons into account - that is, the timeline associated with special issues of the journal. Rookie mistake. 2017 would be the year that I learned that the timeline for special issues was much, much longer than for regular issues. Case in point: Although it might appear from various angles that I had a role in issue 18(1), all of the heavy lifting for this issue (approval, organization, etc.) was already completed before I began my tenure. With a new category for my system came new realizations.

With eons now on my radar, I would also come to learn that the publication of special issues disrupts the regularly scheduled publication of regular submissions. For example, there are no English language mathematics education articles in 17(1), 17(2) is a special issue, 17(3) houses many math education articles (e.g., Francis et al., 2017; Hyslop-Margison et al., 2017; Pyper, 2017; Towers et al., 2017), and Watson and English (2017) is the only English language math education article in 17(4). Each of these articles, which came to me at different times and took varying amounts of time to get published, represents the ebbs and flows of the journal and the role of special issues, which finally started to make a bit more sense. Playing with the abstract notions of time would also, eventually, change my relationship with certain members of the editorial board.

Depending on the Kindness of Board Members (2017)

Besides getting acquainted with eons, the other valuable lesson that I learned in 2017 was that members of the editorial board could and should be utilized as reviewers. This may not come as a surprise. The challenge, for me, was gathering the courage to bother a very prominent member of the mathematics education community with, essentially, a task. Best case scenario, they respond to your email and agree to take on the task. Worst-case scenario, they respond and say "thanks, but no thanks" to your request. If it is the latter, hey, at least they know you are alive and your role with the journal. Well, actually, the worst-case scenario would be sending an email and getting no response. "Ghosted," as the kids say. I should note that, during all my time as math education editor at @ CJSMTE, I have only been ghosted twice. By and large, when I put out requests to members of the board, they are more than willing to help out. And for that, I would like to thank those who have agreed to my requests over the years.

Among the 30 manuscripts that crossed my desk in 2017, there were a number that I could not decide whether to send out for review. Having recently received praise from a few reviewers about the quality of 
the manuscripts that were being sent out for review, I decided to ask some members of the editorial board for their opinion. The advice I received in these instances was invaluable; moreover, I realized that I had been overlooking a key resource. Many of the board members hold, or held, various editorial positions for mathematics education journals, have reviewed countless manuscripts, and are well-versed in the mathematics education research literature. In other words, the editorial board was full of super reviewers! How had I not seen it before?! Or had I let being ghosted keep me from reaching out to such a valuable, knowledgeable group of individuals? After this realization, depending on the kindness of the editorial board came to have two meanings for me. On the one hand, in certain instances I came to depend on the kindness of certain members of the editorial board to complete tasks that I sent them. On the other hand, whether or not members of the board would be involved with certain tasks, with all due respect, depended on their kindness. At the end of 2017, I had sussed out depending on the kindness of board members; however, I would soon learn that the editorial board was about to go through a major overhaul, which meant I would have to muster up courage once again with the new board. Actually, everything as I knew it was about to go through a major overhaul as we switched publishers.

\section{The Springer Era (2018-Present)}

Ch-ch-ch-ch-changes (2018)

The change in publishers, from Taylor and Francis to Springer, went rather smoothly for me, given that the bulk of the work required to pull off such a major change was done by others. Done so well, in fact, that I was able to simply focus on the articles in my hopper (a.k.a., cue) and learn a new system. At the same time, other big changes were taking place.

Along with the change in publishers, @CJSTME would also undergo a change in Editor in Chief (EIC) in 2018. After many, many years at the helm, John Wallace retired as EIC. Despite having worked together for 3 years, John and I never met face to face. We did, however, have numerous phone calls and exchanges. By and large, John and I saw eye to eye on nearly every issue that we discussed. The new human, then, would have some rather big shoes to fill.

In 2019, Doug McDougall, the new EIC of @CJSMTE, picked things up seamlessly, in my opinion. He also made the effort, as John had done a number of years ago, to pick up the phone and give me a callhowever, in this case, it was he who was at the beginning of his tenure at @ CJSMTE. Full disclosure: Doug and I already knew each other before the phone call. He, a senior scholar in mathematics education in Canada, and I had met and spoken at various mathematics education conferences over the years. After just a few minutes of speaking on the phone, I had a sense of calm and a sense of confidence that the transition, not only of publishers but also of EICs, would be smooth. My attention returned to the articles in my hopper and to learning the new system.

The Onslaught That Never Was (2018 and 2019)

With Doug at the helm, a new angle emerged to which, initially, I did not pay much attention. In essence, as the EIC of @CJSMTE, Doug is the final arbiter for the math, science, and technology manuscripts. Period. But, he was also like me - that is, an English language mathematics education editor. Knowing this filled me with a sense of calm. Whether it was me or Doug, one of us could be a sober second thought on any and all English mathematics education articles, when necessary. This was an especially comforting thought at the time, given that I was expecting an onslaught of articles with the move to Springer.

2018 and the change to Springer began with the publication of a special issue that was already on the books before my tenure. While I do not recall if the issue was planned to help with the transition, 18(1) gave us all the opportunity to learn to navigate the new system and get back to our new normal. With $18(3)$ also 
being a special issue, there was very little room for an onslaught of submissions. I did notice a bit of an increase in the number of submissions once the transition was made; however, the 39 manuscripts that crossed my desk in 2018 did not represent a marked increase in manuscripts from previous years.

Of all the manuscripts submitted, mathematics education is well represented in the first few issues with Springer, thanks in large part to the work of Kajander \& Lovric (2018) and Kajander et al. (2018) in 18(2), and Zazkis \& Marmur (2018) and Hall \& Suurtamm (2018) in 18(4). I was pleased to see such interesting work housed in our "new" journal during the first year of existence. The same can be said for the second year.

2019 began with two special issues. The first, "Mathematics Education in the News," (Barwell \& Abtahi, 2019) was the second special issue where I provided some input at the proposal stage (Aikenhead, 2017, being the first), which felt like eons ago at the time. Given the individuals involved and the strength of the proposal, it was an easy and resounding "yes" on my part. Beyond my initial support, I reviewed a few of the manuscripts that were submitted, and even contributed my own commentary (Chernoff, 2019). My involvement with this issue stands in stark contrast to the second special issue of the year, which was published solely in French. This issue brought home a sad reality for me and my work at @ CJSMTE.

The problem, in a nutshell, is that I have no clue what is happening in the French language portion of the journal. Now, I will admit: I do not consistently pore over the science and technology articles each time I open an issue of @CJSMTE, either. However, regardless of the content area, I never read the French language articles. While my Grade 12 French teacher (who I hope is not reading this) knows that I would at least be able to get the gist of what is written, he would also know that it does not come "naturally" to me.

Given that 2019 had two special issues on the books, there were once again only two issues left to house manuscripts. If you have been a regular reader of the journal over the years, you may have noticed that, since the transition to Springer, we have been given greater leeway to publish more, and longer articles. This was a topic of lengthy discussion at the 2019 Editors' Retreat in Toronto; we were all happy about the increase in the number of articles per issue, and came to a conclusion that pleased most regarding a word limit for articles. Many other topics were discussed over our 2-day meeting and many important decisions were made. Perhaps the decision that pleased me the most was that my suggestion to add Professors Ralph Mason, University of Manitoba, and Ann Kajander, Lakehead University, to the Editorial Board of @ CJSMTE was accepted not only by the board but also by the individuals themselves.

By the beginning of 2019, I had handled approximately 125 manuscripts in my role as math education editor of @CJSMTE. By the end of the year, I had handled 36 more. Of those 36 manuscripts, a few made their way into the pages of issue 19(3) - e.g., Takeuchi et al. (2019) — and issue 19(4) - e.g., Voutsina (2019), and Coles and Sinclair (2019). The accepted articles, I remember; I would not be able to recall details about the 33 manuscripts that were rejected that year quite as quickly. And yet...

Seeing Ghosts Out There (2019)

Sam Darnold, quarterback of the New York Jets, received a lot of heat from the (North American) football community in the fall of 2019. In a widely shared clip, while mic'd up for a game, Darnold proclaimed that he was "seeing ghosts on the field." What Darnold was referring to was seeing players from the other team, the defense in particular, where they were not. For example, at a certain point in the game, he may have thought that someone was rushing to tackle him, but the game tape would later reveal this not to be the case. In other words, it was as if he was seeing ghosts. The phrase is mostly attributed to new quarterbacks who are doing their best to learn the game at the professional level. I, too, started seeing ghosts in 2019, but not in the context of professional football.

If you are like me, you keep tabs on new issues of various journals via email alerts. Once a new issue of, say, Mathematical Thinking and Learning has been released, an email is sent to my inbox with the Table of Contents. Typically, you will find the titles of the articles in the issue and the names of the authors; any further details require you to click on the link, which sends you to the journal's website. In 2019, somewhere 
between manuscripts 126 and 162, I saw my first ghost. I do not remember which article it was, exactly, but I do remember scrolling through the Table of Contents of another journal when I stopped and felt a rushor, more accurately, a sense of panic. I can still hear myself saying, "[Expletive], is that the article I rejected?!" Immediately, I tried to recall the details, to no avail. The train of thought continued: "Did it even get reviewed? Did I reject it before it even go to the reviewing stage? No, there's no way... Or is there a way? Did I miss something? What did I miss!?" With the answers to my questions not coming to mind, I stopped what I was doing and went to my big computer.

My "big computer" is where I house all of my emails. That is right, if you have ever sent me an email, I have it. As a keeper of emails, I have also gotten quite good at searching through old emails. Searching the title of the manuscript (and using a few other tricks up my sleeve) provided no results. Phew! But then I thought, "Wait, what if the editors wanted a title change?" I was not off the hook just yet. I typed the names of the author(s) into my big computer. Again, nothing! Finally, I was able to relax - it was just a ghost.

The problem with seeing your first ghost, if you have ever had the pleasure, is that you then start seeing them more frequently, or so it seems (i.e., Baader-Meinhof phenomenon). For a period of time, a period longer than I would like to admit, I was seeing ghosts everywhere. Table of Contents after Table of Contents, and there I would be, walking over to my big computer, making sure that the article that was just published was not one that had come across my desk and been rejected. Sometime after the tenth ghost, I started to realize that, no, I was not saying no to work that was deemed worthy elsewhere. Phew! That said, every so often, when a new Table of Contents for a journal comes out, I still sometimes have that moment of doubt where I say to myself, "Did I...?” only to catch myself (or, just to make sure, double check).

\section{A Fractured Special Issue of @ CJSMTE (2020)}

As was the case the previous year, the 2019 @CJSMTE Editors' Retreat was an intense few days in Toronto. Thanks to Doug and Sofia's extreme organization, we addressed many, many topics. The topic that really drew me in, though, was the journal's 20-year anniversary, which would take place in 2020. In fact, as a fan of anniversaries (e.g., Chernoff et al., 2016; Chernoff \& Sterenberg, 2014; Chernoff et al., 2019), I already had a plan in the works before the meeting, and it was time to see if I could bring it to fruition.

Looking to mimic but expand upon the idea found in a recent issue of Educational Studies in Mathematics, I proposed a Special Issue: Editor's Choices from the Canadian Journal of Science, Mathematics, and Technology Education: Celebrating 20 Years of Mathematics Education. The plan was simple, really. We would ask the three current editors-McDougall (Editor in Chief), Lajoie (French Math Editor), and myself (English Math Editor) — and the past math editors-Hanna (founding editor), Zazkis (English), and Sinclair (French) - to make two contributions each.

First, we would each choose an article that had been published during our respective tenures as Editors, which would be republished in this special issue. Second, we would each write a commentary on the article we chose. Beyond those two broad points, given the caliber of individuals that would be involved, the rest was up to them. They could dedicate their commentary to the article they chose and why they chose it. Or, perhaps the article could be used as a springboard to detail and reflect on their experience serving as an editor for @ CJSMTE. Alternatively, their chosen article might serve as a catalyst to write a commentary on the impact of the author on the field of mathematics education. Or maybe the article would inspire, say, a commentary on the state of the field of mathematics education research during their time as editor, on the state of mathematics education research currently, or on the future of mathematics education. Ultimately, whatever angle they chose, I trusted the editors to pay homage to the 20 years of mathematics education as housed in @CJSMTE. By the time we left Toronto, the year was set. The idea of a 20th anniversary issue was enthusiastically embraced, and not only would issue 20(3) become the math editors' special issue, issue 20(4) would commemorate 20 years of @CJSMTE across Science, Mathematics, and Technology. However, there were now issues of timing and space that needed to be addressed. 
As mentioned, the move to Springer has resulted in a move to longer articles and more articles per issue. As a result, the journal has been featuring more Special Themes, in addition to Special Issues. A Special Theme, as is the case in other journals, can be seen as a Special Issue within a regular issue. Issue 20(1), for example, featured the Special Theme of "Engineering Education," and issue 20(2) featured the Special Theme "Putting the 'M' in STEM." Still on my way back from Toronto, I suddenly realized that we were quickly running out of room for the articles I had in the hopper. Informing an author or authors that their article has been accepted is always a nice moment. Telling them their article was accepted but they would have to wait over a year to see it in print-nice, but not quite as nice.

It is also always a nice moment when reviews come in earlier than expected. Back at home, early reviews (which are actually more frequent than I ever expected) came in for a few articles that I had in the hopper, which meant that we were able to publish the Holm and Kajander (2020) article outside of the theme, but within the "Engineering Education" special-themed issue. Similarly, the Hanin and Van Nieuwenhoven (2020) and Yan et al. (2020) articles fall outside the theme of "Putting the 'M' in STEM," but still appear in issue 20(2). I have always been on the fence about outside-of-the-theme articles found in special-themed issues, but from my new editorial perspective, I see the importance of getting accepted articles to print in a timely fashion. As it would turn out, though, all my worrying about long waits was for naught.

One morning, not so long ago, Editor's Choices from the Canadian Journal of Science, Mathematics, and Technology Education: Celebrating 20 Years of Mathematics Education was no more. Essentially, Springer objected to reprinting articles because, and I am paraphrasing here, why would someone pay for articles that were already printed? Not looking to delve into this topic any further at this moment, I will instead contend that what happened next demonstrated the robustness of the journal. Being told just a few months out that what you had planned for an issue has to be scrapped entirely could be a problem. Fortunately, for us, it was not that big of a problem. Saving the day? The number of articles that we have in the cue. Thus, and with 20(4) being a special issue, a number of articles that would have been published in 2021 have made their way into issue 20(3). While I was crestfallen when I found out that my special issue idea would not come to fruition, as always, I am pleased to see the publication of articles that I have been involved with, such as Shin (2020).

Although issue 20(3) does not exist in the manner in which it was originally conceived, it does exist in a fractured sense. As you will see in this issue, there are Anniversary Editorials from Lajoie, and me. Furthermore, articles from other former editors will appear in issue 20(4). Thus, although the proposed issue did not come to fruition, much of the spirit of the original idea has been preserved, which brings me back to present day.

\section{Odds and Ends}

Submission of this, my anniversary editorial, took place on June 30, 2020. For those of you keeping track, that is right -5 years, to the day, from my very first assignment with @ CJSMTE. How times have changed.

Barring a scant few trips to the grocery and beer store, my wife and I have been self-isolating ever since the Canadian Prime Minister, in response to the COVID-19 pandemic, told Canadians in late March of 2020 that "Enough is enough. Go home and stay home." We went home, and we stayed home. As it is currently the end of June, months since the order, the provinces and the country are beginning to open back up. Taking advantage of the opportunity, my wife and I are spending several days in Jasper as we make our way to visit our elderly parents in Kamloops and Chilliwack, British Columbia. Fittingly, given that it is the anniversary of my first assignment, I am back at the Bear Paw Bakery. Unlike in 2015, I am not beholden to the Bear Paw's Wi-Fi and a phone with a tiny screen. In fact, one might say that, with my 2018 iPad Pro, the Apple Pencil, the PDF Expert application, and a data plan, the journal is now with me $24 \mathrm{~h}$ a day, 7 days a week, 365 days a year. In that sense, it has become a part of, or an extension, of me.

The success of the English language mathematics section of @ CJSMTE can be directly attributed to two groups of people: the authors and the reviewers. I would therefore like to take this opportunity to thank 
everyone who has contributed to the journal while I have been involved as math education editor. Thank you for your work, and thank you for choosing @CJSMTE as a publication venue. I would also like to thank all of the authors whose manuscripts did not, for various reasons, make it to the publication stage. In the last part of my rejection emails, I always ask the author or authors to take our comments in the spirit in which they are intended: to help in future efforts at making the manuscript suitable for publication elsewhere. Finally, I would like to pay a very special thanks to those whose efforts also do not grace the pages of @CJSMTE, yet make everything that happens here at the journal possible: the reviewers.

Still an ardent reviewer for other journals myself, I now see many sides to the reviewing process. On the one hand, reviewing manuscripts is not glamorous, and recognition is not public. That said, things are changing, and reviewers now have opportunities to be recognized for their reviewing efforts with, for example, Publons. On the other hand, without reviewers, the whole notion of academic publishing would come to a grinding halt. From the role of an editor, then, finding reviewers is a delicate balancing act, and finding what I call the Reviewer Sweet Spot, a combination of expertise, career trajectory, willingness, etc., is no easy task.

I will be honest: There is nothing concrete that I can offer in return when I ask someone to review an article for us at @CJSMTE. Of course, as is the case with other journals, consistently contributing strong, on-time reviews over an extended period of time would rightly warrant consideration for a seat on the editorial board. Playing the long game, though, is tough to swallow if I send a manuscript to be reviewed at the end of the semester when everyone is up to their eyeballs in marking and grades. Never knowing what to expect after sending out invitations to review, I have seen a lot from reviewers over the last 5 years.

I rate responses I receive from reviewers on what I call a Satisfaction Scale. High on the Satisfaction Scale: sending out a request to someone who is an expert in the given topic, and who accepts the assignment shortly after it was sent. The simple pleasures in life, indeed. Lower on the scale (and with all due respect to those who will read between the lines and figure out that I am talking about them): sending a request to someone involved with another mathematics education journal. I know that, in these instances, I will get a "yes," and a great review from someone well versed in the field of mathematics education. What I will also get, in very short course, is a request to review a manuscript from, you guessed it, the journal that the person who just said "yes" is involved with. Squid, pro, row, as Austin Powers would say. Even lower on the scale, and as previously discussed: getting ghosted. The lowest of the low on the scale, however, for me, is inviting a person to be involved with a project, having that person agree to be involved, and sending them an email asking to review an article for @ CJSMTE... only to have them decline the offer to review. Serves me right, I guess. No matter where a reviewer response ends up on my spectrum, though, I always look forward to reading what they have to say about the manuscripts they review.

And so, I would like to thank each and every one of the people who has reviewed an English language mathematics manuscript for @ CJSMTE over the last 5 years. Thank you to the reviewer who once said, and I am paraphrasing here, "Quit wasting my time. Why you ever sent this garbage out for review is beyond me!" Thank you as well to the reviewer who said, and again I am paraphrasing, "Either the author of this manuscript has no clue what they are doing or talking about or they are so brilliant that I am unable to comprehend the scale of what they are doing at this point of their and my career. I will leave it to you to decide." To the members of the editorial board who are quick to review manuscripts when I am on the fence about sending them out for review, thank you. To those of you who always get your reviews done in a timely manner, thank you. To the mathematicians who have reviewed for the journal, thank you. And, to the Canadian mathematics educators who have reviewed for the journal, a special thank you.

If you are a Canadian mathematics educator, expect an email from me requesting a manuscript review. On that note, as a Canadian mathematics educator, you should also consider submitting your work to our journal. You should even consider submitting a proposal for a Special Issue. Sure, there are many, many other options out there. There might even be reasons deterring you from considering @ CJSMTE; but do not let, for example, typing the journal's name into Google (or any other web browser) and have the top two hits on the search page be for the old publisher deter you from submitting; we will get that figured out, eventually. And do not let the fact that I am still learning, too, deter you from submitting. I have only ever 
been involved with one erratum (sorry!), thus far, but I simply cannot guarantee it will not happen again in the future. I will, though, guarantee that I will try my best to not make it happen. Sure, I am biased, but I know, for sure, that @ CJSMTE is a great option for publishing your work.

Simply put, it is a new reality, and the demands of the modern-day university have resulted in certain demands when it comes to publishing research. Within this new reality, I contend, @ CJSMTE has a lot going for it. Major publishing company: check. Print and digital options: check. Open access options available: check. Outstanding editorial board: check. Listed in the Web of Science: check. Digital Object Identifier: check. Reasonable time from submission to first decision and acceptance: check. The list goes on and on. As such, no matter the stage of your career, I ask that you consider @ CJSMTE as a publication venue for your mathematics education research. Again, I am biased, but I would like nothing more than for @ CJSMTE to be known for its mathematics education content; and, between now and our silver anniversary, I will do my best to help make it happen. Should you have an article published in @ CJSMTE in the next few years, congratulations; and, should you decide to celebrate the occasion with a drink, I highly recommend Canadian beer. (I think that was, like, my best confession ever, eh!?)

\section{References}

Aikenhead, G. S. (2017) Enhancing school mathematics culturally: A path of reconciliation. Canadian Journal of Science, Mathematics and Technology Education, 17(2), 73-140. https://doi.org/10.1080/14926156.2017.1308043

Barwell, R. \& Abtahi, Y. (2019). Mathematics education in the news: Introduction. Canadian Journal of Science, Mathematics and Technology Education, 19, 1-7. https://doi.org/10.1007/s42330-019-00043-Z

Chernoff, E. (2010). Editorial: Two years and four issues later. vinculum: Journal of the Saskatchewan Mathematics Teachers' Society, 2(2), 2-6.

Chernoff, E. J. (2017). The Canadian Journal of Science, Mathematics and Technology Education: Meet the editors. Ad-hoc presentation report for the proceedings of the 40th annual meeting of the Canadian Mathematics Education Study Group/ Groupe Canadien d'Étude en Didactique des Mathématiques. (pp. 253-254).

Chernoff, E. J. (2019). The Canadian math wars. Canadian Journal of Science, Mathematics and Technology Education [Special Issue: Mathematics Education in the News], 19(1), 73-76. https://doi.org/10.1007/s42330-018-0037-9

Chernoff, E. J. \& Mamolo, A. (2015) Unasked but answered: comparing the relative probabilities of coin flip sequence (attributes). Canadian Journal of Science, Mathematics and Technology Education, 15(2), 186-202. https://doi. org/10.1080/14926156.2015.1031410

Chernoff, E. J. \& Russell, G. L. (2012). The fallacy of composition: Prospective mathematics teachers' use of logical fallacies. Canadian Journal of Science, Mathematics and Technology Education, 12(3), 259-271. https://doi.org/10.1080 /14926156.2012.704128

Chernoff, E. J. \& Sterenberg, G. (Eds.) (2014). Selected writings from the Journal of the Mathematics Council of the Alberta Teachers' Association: Celebrating 50 years (1962-2012) of delta-K. Charlotte, NC: Information Age Publishing. (500 pages.)

Chernoff, E. J., Liljedahl, P., \& Chorney, S. (Eds.) (2016). Selected writings from the Journal of the British Columbia Association of Mathematics Teachers: Celebrating 50 (1962-2012) years of Vector. Charlotte, NC: Information Age Publishing.

Chernoff, E. J., Russell, G. L., \& Sriraman, B. (Eds.) (2019). Selected writings from the Journal of the Saskatchewan Mathematics Teachers' Society: Celebrating 50 years (1961-2011) of vinculum. Charlotte, NC: Information Age Publishing.

Chorney, S., Ng, O., \& Pimm, D. (2016) A tale of two more metaphors: Storylines about mathematics education in Canadian national media. Canadian Journal of Science, Mathematics and Technology Education, 16(4), 402-418. https://doi. org/10.1080/14926156.2016.1235746

Coles, A. \& Sinclair, N. (2019). Re-thinking 'concrete to abstract' in mathematics education: Towards the use of symbolically structured environments. Canadian Journal of Science, Mathematics and Technology Education, 19, 465-480. https://doi. org/10.1007/s42330-019-00068-4

Francis, K., Bruce, C., Davis, B., Drefs, M., Hallowell, D., Hawes, Z., McGarvey, L., Moss, J., Mulligan, J., Okamoto, Y., Sinclair, N., Whiteley W., \& Woolcott, G. (2017) .Multidisciplinary perspectives on a video case of children designing and coding for robotics. Canadian Journal of Science, Mathematics and Technology Education, 17(3), 165-178. https://doi.org/10.1080/14926156.2017.1297510 
Hall, J. \& Suurtamm, C. (2018). Behind the "success story": Exploring the experiences of a woman mathematics major. Canadian Journal of Science, Mathematics and Technology Education, 18, 342-354. https://doi.org/10.1007/s42330018-0032-1

Hanin, V., \& Van Nieuwenhoven, C. (2020). An exploration of the cognitive, motivational, emotional and regulatory behaviours of elementary-school novice and expert problem solvers. Canadian Journal of Science, Mathematics and Technology Education. 20, 312-341. https://doi.org/10.1007/s42330-020-00092-9

Holm, J. \& Kajander, A. (2020). Seeking intersections: Math degrees, beliefs, and elementary teacher knowledge. Canadian Journal of Science, Mathematics and Technology Education, 20, 27-41. https://doi.org/10.1007/s42330-019-00069-3

Hyslop-Margison, E., Rogers, M., \& Oladi, S. (2017). Education research as analytic claims: The case of mathematics. Canadian Journal of Science, Mathematics and Technology Education, 17(3), 145-151. https://doi.org/10.1080 /14926156.2017.1327623

Kajander, A. \& Holm, J. (2016). What math matters? Types of mathematics knowledge and relationships to methods course performance. Canadian Journal of Science, Mathematics and Technology Education, 16(3), 273-283. https://doi. org/10.1080/14926156.2016.1183837

Kajander, A. \& Lovric, M. (2018). "It does not exist": Infinity and division by zero in the Ontario mathematics curriculum. Canadian Journal of Science, Mathematics and Technology Education, 18, 154-163. https://doi.org/10.1007/s42330018-0012-5

Kajander, A., Flessa, J., Lampo, A. et al. (2018). Pitfalls of autonomy: The overlooked challenges of teaching locally developed mathematics in Ontario High Schools. Canadian Journal of Science, Mathematics and Technology Education, 18, 164176. https://doi.org/10.1007/s42330-018-0013-4

Kontorovich, I. (2016). We all know that a $0=1$, but can you explain why? Canadian Journal of Science, Mathematics and Technology Education, 16(3), 237-246. https://doi.org/10.1080/14926156.2016.1189623

Pyper, J. S. (2017). Learning about ourselves: A review of The Mathematics Teacher in the Digital Era. Canadian Journal of Science, Mathematics and Technology Education, 17(3), 234-242. https://doi.org/10.1080/14926156.2017.1297509

Rodney, S., Rouleau, A., \& Sinclair, N. (2016). A tale of two metaphors: Storylines about mathematics education in Canadian national media. Canadian Journal of Science, Mathematics and Technology Education, 16(4), 389-401. https://doi. org/10.1080/14926156.2016.1235747

Shin, D. (2020). Prospective mathematics teachers' professional noticing of students' reasoning about mean and variability. Canadian Journal of Science, Mathematics and Technology Education, 20(3). https://doi.org/10.1007/s42330-02000091-w

Smith, R. C., Kim, S., \& McIntyre, L. (2016). Relationships between prospective middle grades mathematics teachers' beliefs and TPACK. Canadian Journal of Science, Mathematics and Technology Education, 16(4), 359-373. https://doi. org/10.1080/14926156.2016.1189624

Takeuchi, M. A., Bryan, V., Valera, S. et al. (2019). Immigrant students' stories about learning mathematics in groups. Canadian Journal of Science, Mathematics and Technology Education, 19, 237-253. https://doi.org/10.1007/s42330019-00056-8

Towers, J., Hall, J., Rapke, T., Martin, L. C., \& Andrews, H. (2017). Autobiographical accounts of students' experiences learning mathematics: A review. Canadian Journal of Science, Mathematics and Technology Education, 17(3), 152-164. https://doi.org/10.1080/14926156.2016.1241453

Voutsina, C. (2019). Context variation and syntax nuances of the equal sign in elementary school mathematics. Canadian Journal of Science, Mathematics and Technology Education, 19, 415-429. https://doi.org/10.1007/s42330-019-00067-5

Watson, J. M. \& English, L. D. (2017). Statistical problem posing, problem refining, and further reflection in Grade 6. Canadian Journal of Science, Mathematics and Technology Education, 17(4), 347-365. https://doi.org/10.1080 /14926156.2017.1380867

Yan, X., Marmur, O. \& Zazkis, R. Calculus for teachers: Perspectives and considerations of mathematicians. Can. J. Sci. Math. Techn. Educ. 20, 355-374 (2020). https://doi.org/10.1007/s42330-020-00090-x

Zazkis, D. (2016). On transitions between representations: The role of contextual reasoning in calculus problem solving. Canadian Journal of Science, Mathematics and Technology Education, 16(4), 374-388. https://doi.org/10.1080 /14926156.2016.1190042

Zazkis, R. \& Marmur, O. (2018). Scripting tasks as a springboard for extending prospective teachers' example spaces: A case of generating functions. Canadian Journal of Science, Mathematics and Technology Education, 18, 291-312. https://doi. org/10.1007/s42330-018-0019-y

Publisher's Note Springer Nature remains neutral with regard to jurisdictional claims in published maps and institutional affiliations. 